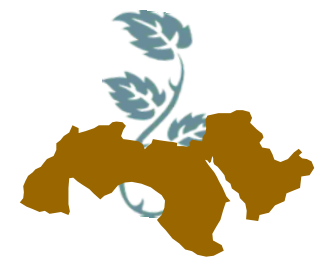

Arab Univ.

J. Agric. Sci., Ain Shams Univ., Cairo, 24(1), 157-168, 2016

\title{
EFFECT OF ACTIVE AND PASSIVE MODIFIED ATMOSPHERE PACKAGING ON QUALITY ATTRIBUTES OF STRAWBERRY FRUITS DURING COLD STORAGE
}

\author{
Ebtsam H. Afifi ${ }^{1}$; M.E. Ragab ${ }^{2}$; H.G. Abd El-Gawad ${ }^{2}$ and M.S. Emam ${ }^{1}$ \\ 1- Vegetables Handling Research Dept., Hort. Res. Institute, ARC, Giza, Egypt. \\ 2- Hort. Dept., Fac. of Agric., Ain Shams Univ., Cairo, Egypt \\ E-mail: Ebtsamh303@yahoo.com
}

Keywords: Strawberry, Modified atmosphere, Packaging, Storage, Shelf life

\section{ABSTRACT}

This study was carried out during 2013-2014 and 2014-2015 seasons at a private farm located at Tokh district, Qalubia Governorate. Strawberry fruits "festival cultivar" to study the effect of active $\left(7.5 \% \mathrm{O}_{2}+15 \% \mathrm{CO}_{2}\right.$ or $\left.10 \% \mathrm{O}_{2}+10 \% \mathrm{CO}_{2}\right)$ and passive modified atmosphere packaging (MAP) on preserving the quality parameters and extend the shelf life of fruits during storage at $0^{\circ} \mathrm{C}$ plus shelf life at $10^{\circ} \mathrm{C}$.The results showed that active MAP inhibit the weight loss and decay percentage, maintained fruit texture, ascorbic acid, titratable acidity (TA) and decrease in color development during storage and shelf life. Passive MAP was less effective in reducing the loss of fruits texture, TA and ascorbic acid content. Untreated MAP (control) gave the highest values of weight loss and decay percentage and lowest values of texture, becoming more red and poor appearance after 15 days of storage at $0^{\circ} \mathrm{C}+2$ days at $10^{\circ} \mathrm{C}$. The results showed also that the optimum gas composition of MAP tests for strawberry was $7.5 \%$ $\mathrm{O}_{2}+15 \% \mathrm{CO}_{2}$. No decay was observed in active MAP at $7.5 \% \mathrm{O}_{2}+15 \% \mathrm{CO}_{2}$ during the storage period plus shelf life. Furthermore, it also retarded texture, color, titratable acidity and ascorbic acid content. Finally, the study concluded that storage of strawberry fruits at active MAP of $7.5 \% \mathrm{O}_{2}+15 \%$ $\mathrm{CO}_{2}$ improved storability of fruits, and maintained fruit quality and gave fruits with good appearance till of 15 days at $0^{\circ} \mathrm{C}+2$ days at $10^{\circ} \mathrm{C}$ without de- cay. The shelf life of strawberry after harvest can be extended to 3 days at $0^{\circ} \mathrm{C}+2$ days at $10^{\circ} \mathrm{C}$ by this treatment.

\section{INTRODUCTION}

Strawberry have short shelf life due to highly perishability and are susceptible to mechanical injury, physiological disorders, water loss, soft texture and decay (Oliveria et al 2015). The shelf life of fresh produce is limited to 1-2 days at room temperature (Wills and Kim, 1995 and Harker et al 2000). The shelf life of fresh strawberry is inversely proportional to respiration rate (Day, 1990). Consequently, the most commonly method for shelf life extension is low temperature. However, storage quality can be further improved by altering the gas atmosphere surrounding the fresh strawberry fruits (Holcroft and Kader, 1999).

Modified atmosphere packaging (MAP) consisting of reduced $\mathrm{O}_{2}$ with elevated $\mathrm{CO}_{2}$ combined with proper refrigeration maintain the quality and extend the shelf life of strawberry by reducing respiration rates, delaying changes in textural properties and color, as well by retarding depletion of total sugars, ascorbic acid and other organic acids (Barrios et al 2014 and Oliveira et al 2015). Attia (2005) found that strawberry fruits showed significant increment in firmness when stored in modified atmosphere conditions than the initial firmness.

MAP has been developed over the last decades as a technique to retain high quality of vegetables. Passive MAP, where effects are derived from product respiration rate and gas permeability of the packaging film, induces a passively established steady state after a long transient period.

(Received 12 November, 2015)

(Revised 17 November, 2015)

(Accepted 19 November, 2015) 
With active MAP, initial gas flushing or the introduction of gas scavenging system with the package is used to accelerate gas composition modification to avoid product exposure to high concentrations of unsuitable gases (Vermeiren et al 1999).

The main benefit, however, of using MAP for strawberry is inhibiting of decay and the generation of $\mathrm{C}_{2} \mathrm{H}_{4}$ because it can influence the enzyme activity, thus the permeability of cell membrane does not increase quickly (Zhang et al 2007). Furthermore, MAP can prevent microbial growth, discoloration and cell destruction and can reduce the risk of infection (Jouki and Khazaei, 2012).

The objective of this work was to evaluate the potential of active and passive modified atmosphere packaging in preserving the quality parameters and extend the shelf life of festival strawberry fruit during storage at $0^{\circ} \mathrm{C}$ plus shelf life conditions at $10^{\circ} \mathrm{C}$.

\section{MATERIALS AND METHODS}

Storage experiment was conducted during two successive seasons of 2013/2014 and 2014/2015 in the laboratory of Vegetables Handling Research Dept. Hort. Res. Inst. At Giza governorate, on the fruits of strawberry Festival cultivar. Transplants were dipped in $0.2 \%$ Rhizolex solution as fungicide for 20 minutes before planting on $24^{\text {th }}$ and $21^{\text {th }}$ of September, 2013 and 2014 respectively in a private farm at Qalubia Governorate, Egypt. Drip irrigation system and agricultural practices were carried out as recommended by the Ministry of Agriculture. Strawberry fruits were harvested at three quarter red stage of maturity (without any defects) in the third week of January of the two seasons 2014 and 2015 and packed directly in venting plastic punnets $(250 \mathrm{~g})$. Each treatment contained 54 punnets, for the following treatments

1. The punnets inserted into the polypropylene bags $(20 \times 20 \mathrm{~cm}) 30 \mu \mathrm{m}$ thinkness and heat sealed, then flushed with a gas mixture at $7.5 \% \mathrm{O}_{2}+15 \% \mathrm{Co}_{2}$ (active $\mathrm{MAP}_{1}$ ).

2. The punnets inserted into the polypropylene bags $(20 \times 20 \mathrm{~cm}) 30 \mu \mathrm{m}$ thinkness and heat sealed, then flushed with a gas mixture at $10 \% \mathrm{O}_{2}+10 \% \mathrm{Co}_{2}$ (active $\mathrm{MAP}_{2}$ ).

3. The punnets inserted into the polypropylene bags $(20 \times 20 \mathrm{~cm}) 30 \mu \mathrm{m}$ thinkness and heat sealed (passive MAP).

4. Punnets that were not placed in polypropylene bags (untreated MAP) were served as control.
The treatments were arranged in a complete randomized design (factorial) and stored at $0^{\circ} \mathrm{C}$ and $90-95 \% \mathrm{RH}$ for 15 days with three replicates. Each replicate consisted of 3 punnets.

The sample for each treatment was taken at random in three replicates and evaluated after 3,6 , 9,12 and 15 days at $0^{\circ} \mathrm{C}$ plus two days at $10^{\circ} \mathrm{C}$ (shelf life).

The following quality measurements were recorded.

\section{Weight loss percentage}

It was estimated according to the equation:

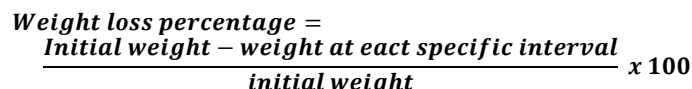

\section{Decay percentage}

Decayed fruits were counted and recorded by visual examination (decayed fruits included all the injured or spoiled, resulting from microorganisms infections) percentage of decay was calculated in relation to total initial weight of stored fruits. (Cheour et al 1990).

3. General appearance based on fresh appearance, fresh calyx and dryness or watery condition , change of color and decay was determined according to the following score system : $9=$ excellent , $7=$ good , $5=$ fair , $3=$ poor, $1=$ unsalable .

4. Texture recorded by TA-1000 texture analyzer instrument using a penetrating cylinder of $1 \mathrm{~mm}$ of diameter, to a constant distance ( 3 and $5 \mathrm{~mm}$ ) inside the pulp of fruits, and by a constant speed $2 \mathrm{~mm}$ per sec., and the peak of resistance was recorded per $\mathrm{g} / \mathrm{cm}^{2}$.

5. Titratable acidity percentage was measured by titration the juice of fruits against $0.1 \mathrm{~N} \mathrm{NaoH}$ to $\mathrm{pH} 8.1$ and expressed as percent of citric acid by A.O.A.C. (2000).

6. Ascorbic Acid: The ascorbic acid content was determined by using 2, 6-dichlorophenol indophenols titration method as described by A.O.A.C (2000).

7. Anthocyanin: It was determined by using $\mathrm{HCl}$ $(1.5 \mathrm{~N})$ spectrophotometer as described by A.O.A.C (2000). 
8. Total sugars was determined in fresh strawberry fruits by using Lane and Eynon method according to A.O.A.C (2000).

All data were subjected to the statistical analysis according to the method described by Snedecor and Cochran (1991).

\section{RESULTS AND DISCUSSION}

\section{Weight loss percentage:}

Data in Table (1) showed that weight loss percentage, of strawberry fruits was increased considerably and consistently with the prolongation of storage period and shelf life during the two seasons. These results agree with those obtained by Shehata et al (2009) and Khreba et al (2014). The loss in weight may be attributed to respiration, transpiration and other senescence related to metabolic processes during storage (Ozkaya et al 2009).
Concerning the effect of MAP on weight loss percentage, data revealed that there were significant differences among MAP treatments, however, active and passive MAP retained their weight during storage and shelf life as compared with untreated MAP (control). Moreover strawberry fruits held in active $\mathrm{MAP}_{1}$ followed by $\mathrm{MAP}_{2}$ resulted in prominent reduction in weight loss percentage during storage and shelf life. These results were true in the two seasons and agreed with those obtained by Ozkaya et al (2009), Jouki and khazaei (2012) and Khreba et al (2014) who found that strawberry fruits kept in MAP maintained their weight than those that packaged under air because dehydration, MAP reduced the water loss by minimizing the contact of fruits with the surrounding air or by inhibiting the diffusion of water vapor with permeability of vapors of the films. On the other hand, the highest values of weight loss percentage was recoded with untreated MAP (control).

Table 1. Effect of active and passive modified atmosphere packaging on weight loss (\%) of strawberry fruits during storage at $0^{\circ} \mathrm{C}$, with an additional 2 days at $10^{\circ} \mathrm{C}$ in $2013-2014$ and $2014-2015$ seasons

\begin{tabular}{|c|c|c|c|c|c|c|c|}
\hline \multirow{3}{*}{ Treatments } & \multicolumn{7}{|c|}{ Storage period (day) } \\
\hline & \multicolumn{6}{|c|}{ 2013-2014 } & \multirow{2}{*}{ Mean } \\
\hline & $0+2$ & $3+2$ & $6+2$ & $9+2$ & $12+2$ & $15+2$ & \\
\hline MAP $_{1}$ & $0.06 \mathrm{q}$ & $0.11 \mathrm{pq}$ & 0.24 no & $0.32 \mathrm{mn}$ & $0.46 \mathrm{kl}$ & $0.63 i$ & $0.30 \mathrm{D}$ \\
\hline $\mathrm{MAP}_{2}$ & $0.10 \mathrm{q}$ & 0.20 op & $0.30 \mathrm{mn}$ & $0.31 \mathrm{~m}$ & $0.51 \mathrm{jk}$ & $0.60 \mathrm{ij}$ & $0.35 \mathrm{C}$ \\
\hline Passive MAP & 0.23 no & $0.34 \mathrm{~m}$ & $0.44 \mathrm{kl}$ & $0.65 \mathrm{i}$ & $0.80 \mathrm{~h}$ & $0.93 g$ & $0.57 \mathrm{~B}$ \\
\hline Control & $1.04 \mathrm{f}$ & $1.95 \mathrm{e}$ & $3.02 \mathrm{~d}$ & $3.75 \mathrm{c}$ & $4.14 \mathrm{~b}$ & $5.23 a$ & $3.19 \mathrm{~A}$ \\
\hline Mean & $0.36 \mathrm{~F}$ & $0.65 \mathrm{E}$ & $1.00 \mathrm{D}$ & $1.28 \mathrm{C}$ & $1.48 \mathrm{~B}$ & $1.85 \mathrm{~A}$ & \\
\hline \multicolumn{8}{|c|}{ 2014-2015 } \\
\hline MAP $_{1}$ & $0.10 \mathrm{~m}$ & $0.12 \mathrm{~m}$ & $0.24 \mathrm{k}-\mathrm{m}$ & $0.50 \mathrm{i}-\mathrm{k}$ & $0.62 \mathrm{~h}-\mathrm{j}$ & $0.71 \mathrm{~g}-\mathrm{i}$ & $0.38 \mathrm{D}$ \\
\hline $\mathrm{MAP}_{2}$ & $0.161 \mathrm{~m}$ & $0.201 \mathrm{~m}$ & $0.43 \mathrm{j}-1$ & $0.61 \mathrm{~h}-\mathrm{j}$ & $0.70 \mathrm{~g}-\mathrm{i}$ & $0.92 \mathrm{f}-\mathrm{h}$ & $0.49 \mathrm{C}$ \\
\hline Passive MAP & $0.25 \mathrm{k}-\mathrm{m}$ & $0.50 \mathrm{i}-\mathrm{k}$ & $0.65 \mathrm{~h}-\mathrm{j}$ & $0.84 \mathrm{f}-\mathrm{h}$ & $0.93 e-g$ & 1.03 ef & $0.70 \mathrm{~B}$ \\
\hline Control & $1.13 \mathrm{e}$ & $1.99 \mathrm{~d}$ & $3.10 \mathrm{c}$ & $3.95 \mathrm{~b}$ & $4.20 \mathrm{~b}$ & $5.50 \mathrm{a}$ & $3.31 \mathrm{~A}$ \\
\hline Mean & $0.41 \mathrm{~F}$ & $0.70 \mathrm{E}$ & $1.11 \mathrm{D}$ & $1.48 \mathrm{C}$ & $1.61 \mathrm{~B}$ & $2.02 \mathrm{~A}$ & \\
\hline
\end{tabular}

Values with capital letters in the same column and the same row are not statistically different. Small letters for interaction. , according to Duncan 's multiple range test.

$\mathrm{MAP}_{1}=$ modified atmosphere packaging at $7.5 \% \mathrm{O}_{2}+15 \% \mathrm{CO}_{2}$.

$M A P_{2}=$ modified atmosphere packaging at $10 \% \mathrm{O}_{2}+10 \% \mathrm{CO}_{2}$. Passive MAP = passive modified atmosphere packaging.

The lowest weight loss percentage from active MAP treatment is due to the confinement of moisture around the produce by polypropylene bags. This increases the relative humidity and reduces vapor pressure deficit and transpiration. In addition, packaging creates a modified atmosphere with higher concentration of $\mathrm{CO}_{2}$ and reduced $\mathrm{O}_{2}$ around the produce which slow down the metabolic processes and transpiration. which diminished the weight loss during storage and shelf life. (Thompson, 1996 and Zhang et al 2007).

The highest weight loss observed in unwrapped fruits throughout the storage period can be attributed to air movement, which tends to sweep away the unstirred layer of air (at aquibrium vapor pressure with the tissues) adjacent to the surface of the produce, thus increasing the vapor pressure deficit (Wills et al 1998). 
The interaction between MAP and storage period was significant, however, in general, strawberry fruits packed in polypropylene film with active $\mathrm{MAP}_{1}$ had the lowest weight loss percentage during all storage periods at $0^{\circ} \mathrm{C}+$ shelf life at $10^{\circ} \mathrm{C}$, compared with all treatments in both seasons of study.

\section{Decay percentage}

Data in Table (2) revealed that decay percentage of strawberry fruits was increased with prolongation of storage period and shelf life. These results were true in the two seasons and in agreement with Jouki and Khazaei (2012) who found that the quantity of decayed strawberry fruits increased with storage time.
Concerning the effect of MAP, data showed that there were significant differences between treatments in decay percentage during storage and shelf life condition. However, strawberry fruits treated with active MAP significantly decreased the percentage of decay in fruits during storage and shelf life compared with passive MAP or untreated MAP (control) in the two seasons. These results were in agreement with Zhang et al (2007); Ozkaya et al (2009) and Mohammadi and Hanafi (2014) who found that MAP significantly prevent strawberry fruits decay and improved the shelf life when compared with unpackaged fruits.

Also El-Kazzaz et al (1983) reported that strawberry fruits exposure to $\mathrm{CO}_{2}$ levels between 5 and $20 \%$ had some fungi static effects on strawberry pathogens.

Table 2. Effect of active and passive modified atmosphere packaging on decay percentage of strawberry fruits during storage at $0^{\circ} \mathrm{C}$, with an additional 2 days at $10^{\circ} \mathrm{C}$ in $2013-2014$ and $2014-2015$ seasons

\begin{tabular}{|c|c|c|c|c|c|c|c|}
\hline \multirow{3}{*}{ Treatments } & \multicolumn{7}{|c|}{ Storage period (day) } \\
\hline & \multicolumn{6}{|c|}{ 2013-2014 } & \multirow{2}{*}{ Mean } \\
\hline & $0+2$ & $3+2$ & $6+2$ & $9+2$ & $12+2$ & $15+2$ & \\
\hline MAP $_{1}$ & $0.00 \mathrm{~d}$ & $0.00 \mathrm{~d}$ & $0.00 \mathrm{~d}$ & $0.00 \mathrm{~d}$ & $0.00 \mathrm{~d}$ & $0.00 \mathrm{~d}$ & $0.00 \mathrm{D}$ \\
\hline $\mathrm{MAP}_{2}$ & $0.00 \mathrm{~d}$ & $0.00 \mathrm{~d}$ & $0.00 \mathrm{~d}$ & $0.00 \mathrm{~d}$ & $0.00 \mathrm{~d}$ & $7.24 \mathrm{c}$ & $1.21 \mathrm{C}$ \\
\hline Passive MAP & $0.00 \mathrm{~d}$ & $0.00 \mathrm{~d}$ & $0.00 \mathrm{~d}$ & $0.00 \mathrm{~d}$ & $0.00 \mathrm{~d}$ & $20.24 b$ & $3.37 \mathrm{~B}$ \\
\hline control & $0.00 \mathrm{~d}$ & $0.00 \mathrm{~d}$ & $0.00 \mathrm{~d}$ & $0.00 \mathrm{~d}$ & $0.00 \mathrm{~d}$ & $23.18 \mathrm{a}$ & $3.86 \mathrm{~A}$ \\
\hline Mean & $0.00 \mathrm{~B}$ & $0.00 \mathrm{~B}$ & $0.00 \mathrm{~B}$ & $0.00 \mathrm{~B}$ & $0.00 \mathrm{~B}$ & $12.67 \mathrm{~A}$ & \\
\hline \multicolumn{8}{|c|}{ 2014-2015 } \\
\hline MAP $_{1}$ & $0.00 \mathrm{~d}$ & $0.00 \mathrm{~d}$ & $0.00 \mathrm{~d}$ & $0.00 \mathrm{~d}$ & $0.00 \mathrm{~d}$ & $0.00 \mathrm{~d}$ & $0.00 \mathrm{D}$ \\
\hline $\mathrm{MAP}_{2}$ & $0.00 \mathrm{~d}$ & $0.00 \mathrm{~d}$ & $0.00 \mathrm{~d}$ & $0.00 \mathrm{~d}$ & $0.00 \mathrm{~d}$ & $10.33 c$ & $1.72 \mathrm{C}$ \\
\hline Passive MAP & $0.00 \mathrm{~d}$ & $0.00 \mathrm{~d}$ & $0.00 \mathrm{~d}$ & $0.00 \mathrm{~d}$ & $0.00 \mathrm{~d}$ & $20.37 b$ & $3.40 \mathrm{~B}$ \\
\hline control & $0.00 \mathrm{~d}$ & $0.00 \mathrm{~d}$ & $0.00 \mathrm{~d}$ & $0.00 \mathrm{~d}$ & $0.00 \mathrm{~d}$ & $26.35 \mathrm{a}$ & $4.39 \mathrm{~A}$ \\
\hline Mean & $0.00 \mathrm{~B}$ & $0.00 \mathrm{~B}$ & $0.00 \mathrm{~B}$ & $0.00 \mathrm{~B}$ & $0.00 \mathrm{~B}$ & $14.26 \mathrm{~A}$ & \\
\hline
\end{tabular}

Values with capital letters in the same column and the same row are not statistically different. Small letters for interaction, according to Duncan 's multiple range test.

$\mathrm{MAP}_{1}=$ modified atmosphere packaging at $7.5 \% \mathrm{O}_{2}+15 \% \mathrm{CO}_{2}$.

$M A P_{2}=$ modified atmosphere packaging at $10 \% \mathrm{O}_{2}+10 \% \mathrm{CO}_{2}$. Passive MAP = passive modified atmosphere packaging.

The reduction in decay and fungal development may be due to active MAP apparently delayed fruits senescence and inhibited microbial growth (Nielsen and Lenfven, 2008) and controlled the exponential growth of microorganisms (Allende et al 2007). Also, Farber (1991) found that $\mathrm{CO}_{2}$ inhibits microbial activity in two ways; it dissolves in water in the product and it has negative effects on enzymic and biochemical activities in cells of both product and microorganisms

The interaction between MAP treatment and storage period was significant. However, the decay started to be shown after 15 days at $0^{\circ} \mathrm{C}+2$ days at $10^{\circ} \mathrm{C}$ for active $\mathrm{MAP}_{2}$, passive MAP and untreated MAP (control). Moreover, it is clear that strawberries packaged in active $\mathrm{MAP}_{1}$ did not show fruits decay during all storage period plus shelf life. More decay was recorded in passive MAP and untreated MAP (control) at the end of storage.

\section{General appearance (GA)}

Data in Table (3) revealed that as expected, general appearance of strawberry fruits was decreased with the prolongation of storage period 
and shelf life and the GA score dropped gradually from excellent to good, fair, poor and unsalable ( 9 , 7, 5, 3, 1). Similar results were reported by Shehata et al (2009). The decrease of GA during storage period might be due to a slight dryness of calyx surface, instead of translucency or macroscopic decay and changes of color.

Table 3. Effect of active and passive modified atmosphere packaging on general appearance (score) of strawberry fruits during storage at $0^{\circ} \mathrm{C}$, with an additional 2 days at $10 \mathrm{C}^{\circ}$ in 2013-2014 and 2014-2015 seasons.

\begin{tabular}{|c|c|c|c|c|c|c|c|}
\hline \multirow{3}{*}{ Treatments } & \multicolumn{7}{|c|}{ Storage period (day) } \\
\hline & \multicolumn{6}{|c|}{ 2013-2014 } & \multirow{2}{*}{ Mean } \\
\hline & $0+2$ & $3+2$ & $6+2$ & $9+2$ & $12+2$ & $15+2$ & \\
\hline MAP $_{1}$ & $9.00 \mathrm{a}$ & $9.00 \mathrm{a}$ & $9.00 \mathrm{a}$ & $9.00 \mathrm{a}$ & $8.33 a b$ & $7.67 \mathrm{ab}$ & $8.67 \mathrm{~A}$ \\
\hline $\mathrm{MAP}_{2}$ & $9.00 \mathrm{a}$ & $9.00 \mathrm{a}$ & $9.00 \mathrm{a}$ & $8.33 \mathrm{ab}$ & $7.67 \mathrm{ab}$ & $5.00 \mathrm{~d}$ & $8.00 \mathrm{~B}$ \\
\hline Passive MAP & $9.00 \mathrm{a}$ & $9.00 \mathrm{a}$ & $9.00 \mathrm{a}$ & $8.33 a b$ & $7.00 \mathrm{a}-\mathrm{c}$ & $3.00 \mathrm{e}$ & $7.56 \mathrm{C}$ \\
\hline control & $9.00 \mathrm{a}$ & $9.00 \mathrm{a}$ & $8.33 a b$ & $7.67 \mathrm{ab}$ & $7.00 \mathrm{a}-\mathrm{c}$ & $1.67 \mathrm{f}$ & $7.11 \mathrm{D}$ \\
\hline Mean & $9.00 \mathrm{~A}$ & $9.00 \mathrm{~A}$ & $8.83 \mathrm{~A}$ & $8.33 \mathrm{~A}$ & $7.50 \mathrm{~B}$ & $4.33 \mathrm{C}$ & \\
\hline \multicolumn{8}{|c|}{ 2014-2015 } \\
\hline MAP $_{1}$ & $9.00 \mathrm{a}$ & $9.00 \mathrm{a}$ & $9.00 \mathrm{a}$ & $9.00 \mathrm{a}$ & $9.00 \mathrm{a}$ & $8.33 a b$ & $8.89 \mathrm{~A}$ \\
\hline $\mathrm{MAP}_{2}$ & $9.00 \mathrm{a}$ & $9.00 \mathrm{a}$ & $9.00 \mathrm{a}$ & $8.33 a b$ & $7.00 \mathrm{a}-\mathrm{c}$ & $5.00 \mathrm{~cd}$ & $7.89 \mathrm{~B}$ \\
\hline Passive MAP & $9.00 \mathrm{a}$ & $9.00 \mathrm{a}$ & $9.00 \mathrm{a}$ & $7.67 \mathrm{ab}$ & $6.33 \mathrm{bc}$ & $3.00 \mathrm{e}$ & $7.33 \mathrm{C}$ \\
\hline control & $9.00 \mathrm{a}$ & $9.00 \mathrm{a}$ & $8.33 a b$ & $7.67 \mathrm{ab}$ & $5.00 \mathrm{~cd}$ & $1.00 \mathrm{f}$ & $6.67 \mathrm{D}$ \\
\hline Mean & $9.00 \mathrm{~A}$ & $9.00 \mathrm{~A}$ & $8.83 \mathrm{~A}$ & $8.17 \mathrm{~A}$ & $6.83 \mathrm{~B}$ & $4.33 \mathrm{C}$ & \\
\hline
\end{tabular}

Values with capital letters in the same column and the same row are not statistically different. Small letters for interaction, according to Duncan 's multiple range test.

$M A P_{1}=$ modified atmosphere packaging at $7.5 \% \mathrm{O}_{2}+15 \% \mathrm{CO}_{2}$. $\mathrm{MAP}_{2}=$ modified atmosphere packaging at $10 \% \mathrm{O}_{2}+10 \% \mathrm{CO}_{2}$.

There were significant differences between MAP treatments and control in general appearance score during storage and shelf life; moreover, active MAP were better than passive MAP or untreated MAP (control). The results proved that active $M_{A P}$ was the most effective treatments for maintained general appearance during storage and shelf life of strawberry fruits. Active $\mathrm{MAP}_{2}$ treatment had slight effects on GA preservation during storage and shelf life. These results are in agreement with those obtained by Jouki and Khazaei (2012) who found that strawberries kept in modified atmosphere maintained appearance better than those that packages under air. The lowest values of GA score was recorded with untreated MAP (control). These results were true in the two seasons. Previous studies showed that MAP delay senescence of strawberry fruits (Jouki \& Khazaei, 2012 and Oliveria et al 2015). MAP made a significant contribution on extending the postharvest longevity of strawberry fruits having a high rate of postharvest water loss (Ozkaya et al 2009).Water saturated atmosphere within the packages controlled water loss and delayed senescence in the absence of water stress and thereby extended postharvest longevity of strawberry fruits (Raid and Jeffrey, 2005).

Besides, MAP can effectively inhibit the cell permeability increasing. Therefore, the shelf life of strawberry was increased accordingly (Zhang et al 2007)

The interaction between MAP treatments and storage period was significant, however, strawberry fruits packed in polypropylene film with active MAP $_{1}$ showed the best appearance, and they did not exhibit any changes in their appearance till $12^{\text {th }}$ days at $0^{\circ} \mathrm{C}+2$ days at $10^{\circ} \mathrm{C}$ and gave product with good appearance after 15 days of storage at $0^{\circ} \mathrm{C}+$ 2 days at $10^{\circ} \mathrm{C}$, while $\mathrm{MAP}_{2}$ treated fruits had good appearance until 12 days at $0^{\circ} \mathrm{C}+2$ days at $10^{\circ} \mathrm{C}$ then dropped to fair level at the end of storage period. On the other hand, untreated MAP (control) resulted in poor appearance after 15 days of storage at $0^{\circ} \mathrm{C}+2$ days at $10^{\circ} \mathrm{C}$. These results were true in the two seasons and agreed with those of Oliveira et al (2015) 


\section{Texture}

Texture of strawberry fruits was continuously decreased with the extending of storage period plus shelf life as presented in Table (4). These results were in agreement with those obtained by Shehata et al (2009); Ozkaya et al (2009) and Jouki \& Khazaei (2012). The decline in fruit texture may be due to the gradually breakdown of proto-pectin to lower molecular fractions which are more soluble in water and this directly correlated with the rate of softening of the fruits (Wills et al 1998).

Concerning the effect of MAP; data revealed that all treatments had significantly greater fruit texture as compared with untreated MAP (control). However, active and passive MAP retained their fruits texture during storage and shelf life as compared with untreated control. Moreover strawberry fruits stored in active $\mathrm{MAP}_{1}$ or $\mathrm{MAP}_{2}$, were the most effective treatments in reducing the loss of

Table 4. Effect of active and passive modified atmosphere packaging on texture $\left(\mathrm{g} / \mathrm{cm}^{2}\right)$ of strawberry fruits during storage at $0^{\circ} \mathrm{C}$, with an additional 2 days at $10^{\circ} \mathrm{C}$ in 2013-2014 and 2014-2015 seasons

\begin{tabular}{|c|c|c|c|c|c|c|c|}
\hline \multirow{3}{*}{ Treatments } & \multicolumn{7}{|c|}{ Storage period (day) } \\
\hline & \multicolumn{6}{|c|}{ 2013-2014 } & \multirow{2}{*}{ Mean } \\
\hline & $0+2$ & $3+2$ & $6+2$ & $9+2$ & $12+2$ & $15+2$ & \\
\hline MAP $_{1}$ & $20.00 \mathrm{a}$ & $19.67 \mathrm{a}$ & $19.33 \mathrm{ab}$ & $18.33 \mathrm{a}-\mathrm{d}$ & $17.33 \mathrm{~b}-\mathrm{e}$ & $17.00 \mathrm{c}-\mathrm{e}$ & $18.61 \mathrm{~A}$ \\
\hline $\mathrm{MAP}_{2}$ & $20.00 \mathrm{a}$ & $19.67 \mathrm{a}$ & $19.33 a b$ & $18.00 \mathrm{a}-\mathrm{d}$ & $17.00 \mathrm{c}-\mathrm{e}$ & $16.67 \mathrm{c}-\mathrm{e}$ & $18.44 \mathrm{~A}$ \\
\hline Passive MAP & $19.67 \mathrm{a}$ & $19.33 a b$ & $19.00 \mathrm{ab}$ & $16.33 \mathrm{de}$ & $15.67 \mathrm{de}$ & $15.33 \mathrm{e}$ & $17.56 \mathrm{~B}$ \\
\hline $\begin{array}{c}\text { Control } \\
\text { Mean }\end{array}$ & $\begin{array}{l}19.67 \mathrm{a} \\
\mathbf{1 9 . 8 3} \mathrm{A}\end{array}$ & $\begin{array}{r}19.33 a b \\
19.50 A B\end{array}$ & $\begin{array}{c}17.33 \mathrm{~b}-\mathrm{e} \\
\mathbf{1 8 . 7 5} \mathbf{B}\end{array}$ & $\begin{array}{c}15.67 \mathrm{de} \\
\mathbf{1 7 . 0 8} \mathbf{C}\end{array}$ & $\begin{array}{l}14.33 \mathrm{e} \\
\mathbf{1 6 . 0 8} \mathrm{D}\end{array}$ & $\begin{array}{l}13.00 \mathrm{f} \\
\mathbf{1 5 . 5 0} \mathrm{E}\end{array}$ & $16.56 \mathrm{C}$ \\
\hline \multicolumn{8}{|c|}{ 2014-2015 } \\
\hline MAP $_{1}$ & $19.67 \mathrm{a}$ & $19.33 \mathrm{ab}$ & $19.00 \mathrm{a}-\mathrm{c}$ & 18.67 a-e & 18.00 a-e & $17.00 \mathrm{de}$ & $18.61 \mathrm{~A}$ \\
\hline $\mathrm{MAP}_{2}$ & $19.67 \mathrm{a}$ & $19.33 a b$ & $19.00 \mathrm{a}-\mathrm{c}$ & 18.00 a-e & $17.67 \mathrm{~b}-\mathrm{e}$ & $16.67 \mathrm{e}$ & $18.39 \mathrm{~A}$ \\
\hline Passive MAP & $19.33 a b$ & $19.00 \mathrm{a}-\mathrm{c}$ & $18.67 \mathrm{a}-\mathrm{d}$ & $17.00 \mathrm{de}$ & $15.33 \mathrm{e}$ & $14.33 \mathrm{f}$ & $17.28 \mathrm{~B}$ \\
\hline $\begin{array}{l}\text { control } \\
\text { Mean }\end{array}$ & $\begin{array}{l}19.33 \mathrm{ab} \\
\mathbf{1 9 . 5 0 A}\end{array}$ & $\begin{array}{c}19.00 \mathrm{a}-\mathrm{c} \\
19.17 \mathrm{~A}\end{array}$ & $\begin{array}{c}18.00 \mathrm{a}-\mathrm{e} \\
\mathbf{1 8 . 6 7} \mathrm{A}\end{array}$ & $\begin{array}{l}15.00 \text { ef } \\
\mathbf{1 7 . 1 7} \mathrm{B}\end{array}$ & $\begin{array}{l}14.00 \mathrm{e} \\
\mathbf{1 6 . 2 5} \mathrm{C}\end{array}$ & $\begin{array}{l}12.33 \mathrm{~g} \\
15.08 \mathrm{D}\end{array}$ & $16.28 \mathrm{C}$ \\
\hline
\end{tabular}

Values with capital letters in the same column and the same row are not statistically different. Small letters for interaction, according to Duncan 's multiple range test.

$\mathrm{MAP}_{1}=$ modified atmosphere packaging at $7.5 \% \mathrm{O}_{2}+15 \% \mathrm{CO}_{2}$.

$\mathrm{MAP}_{2}=$ modified atmosphere packaging at $10 \% \mathrm{O}_{2}+10 \% \mathrm{CO}_{2}$. Passive MAP $=$ passive modified atmosphere packaging

fruit texture with no significant differences between them, passive MAP was less effective in reducing the loss of fruit texture, while the lowest values of texture were found in untreated MAP (control). These results were in agreement with those obtained by Ozkaya et al (2009) and Jouki \& Khazaei (2012).

The favorite effect of MAP in maintained fruits texture could be due to that active MAP can effectively inhibit the permeability of cell membrane (Zhang et al 2007), consequently the fruit texture was maintained during storage. In the meantime, Harker et al (2000) and Attia (2005) found that $\mathrm{CO}_{2}$ treatment enhanced firmness of strawberry fruits. they added that firmness enhancement is due to an increase in the strength of cell to cell bonding; and changes in conductivity of the a poplast, but not of the symplast, which occur during $\mathrm{CO}_{2}$ treatment. They also stated that mechanism for $\mathrm{CO}_{2}$ enhancement of firmness is associated with changes in the $\mathrm{pH}$ of the poplast. Shehata et al (2009) reported that strawberry fruits stored in MAP are firmer than those stored in air. Therefore, any treatment capable of delaying softening is potentially helpful to extend the postharvest life and maintain the product quality.

The interaction between MAP treatments and storage period was significant in the two seasons. It is worth noting that active $\mathrm{MAP}_{1}$ or $\mathrm{MAP}_{2}$ maintained the fruit texture for 15 days at $0^{\circ} \mathrm{C}+2$ days at $10^{\circ} \mathrm{C}$, however, passive MAP treatment maintained the texture for 6 days at $0^{\circ} \mathrm{C}+2$ days at $10^{\circ} \mathrm{C}$ from storage, then lost more rapidly until the end of storage. 


\section{Titratable acidity: (TA)}

Data in Table (5) showed that titratable acidity content of strawberry fruits was decreased with the prolongation of storage period and shelf life for all treatments. These results agreed with those obtained by Khreba et al (2014). This reduction in fruit acidity during storage might be attributed to the rate of oxidation of pyruvic acid and other acids to carbon dioxide (Wills et al 1998).

There were significant difference between MAP treatments in TA content during storage period and shelf life. However, strawberry fruits packed in Active $\mathrm{MAP}_{1}$ was significantly higher in TA as compared with other treatments or untreated MAP (control). Active $\mathrm{MAP}_{2}$ or Passive MAP were less effective in reducing TA loss during storage and shelf life with no significant differences between them. The lowest values of TA content resulted from untreated MAP (control). These results were true in the two seasons of the study. Besides they were in agreement with those obtained by Jouki and Khazaei (2012) and Khreba et al (2014) who found that strawberry fruits stored in MAP exhibited the highest TA content during storage. These results might be attributed to that active MAP (low $\mathrm{O}_{2}$ and high $\mathrm{CO}_{2}$ ) might slowing down the strawberry respiration rate; therefor it can delay in the use of organic acid in the enzymatic reaction of respiration (Zhang et al 2007) which can result in an altered flavor character. Also, Mohammadi and Hanafi (2014) found that the acidity of strawberry fruits stored under MAP decreased slightly.

Table 5. Effect of active and passive modified atmosphere packaging on titratable acidity (\%) of strawberry fruits during storage at $0^{\circ} \mathrm{C}$, with an additional 2 days at $10^{\circ} \mathrm{C}$ in 2013-2014 and 2014-2015 seasons.

\begin{tabular}{|c|c|c|c|c|c|c|c|}
\hline \multirow{3}{*}{ Treatments } & \multicolumn{7}{|c|}{ Storage period (day) } \\
\hline & \multicolumn{6}{|c|}{ 2013-2014 } & \multirow{2}{*}{ Mean } \\
\hline & $0+2$ & $3+2$ & $6+2$ & $9+2$ & $12+2$ & $15+2$ & \\
\hline MAP $_{1}$ & $1.000 \mathrm{a}$ & $0.970 \mathrm{ab}$ & 0.940 a-c & 0.914 a-d & 0.902 a-d & $0.891 \mathrm{a}-\mathrm{d}$ & $0.936 \mathrm{~A}$ \\
\hline $\mathrm{MAP}_{2}$ & $0.950 \mathrm{a}-\mathrm{c}$ & 0.911 a-d & $0.902 \mathrm{a}-\mathrm{d}$ & $0.883 \mathrm{a}-\mathrm{d}$ & 0.865 a-e & $0.840 \mathrm{~b}-\mathrm{e}$ & $0.892 \mathrm{~B}$ \\
\hline Passive MAP & 0.938 a-d & $0.903 \mathrm{a}-\mathrm{d}$ & $0.882 \mathrm{a}-\mathrm{d}$ & 0.863 a-e & $0.832 b-e$ & $0.815 \mathrm{~b}-\mathrm{e}$ & $0.872 \mathrm{~B}$ \\
\hline Control & $0.940 \mathrm{a}-\mathrm{c}$ & 0.890 a-d & $0.840 \mathrm{~b}-\mathrm{e}$ & $0.810 \mathrm{c}-\mathrm{e}$ & $0.780 \mathrm{de}$ & $0.710 \mathrm{e}$ & $0.828 \mathrm{C}$ \\
\hline Mean & $0.957 \mathrm{~A}$ & $0.919 \mathrm{AB}$ & $0.891 \mathrm{BC}$ & 0.868 B-D & $0.845 \mathrm{CD}$ & $0.814 \mathrm{D}$ & \\
\hline \multicolumn{8}{|c|}{ 2014-2015 } \\
\hline MAP $_{1}$ & $1.021 \mathrm{a}$ & $1.000 \mathrm{a}-\mathrm{c}$ & $0.970 a-c$ & 0.920 a-d & 0.870 a-e & 0.852 a-e & $0.939 \mathrm{~A}$ \\
\hline $\mathrm{MAP}_{2}$ & $1.011 \mathrm{ab}$ & $0.903 \mathrm{a}-\mathrm{d}$ & $0.882 \mathrm{a}-\mathrm{d}$ & 0.845 a-e & 0.812 a-e & $0.774 \mathrm{c}-\mathrm{e}$ & $0.871 \mathrm{~B}$ \\
\hline Passive MAP & $1.008 \mathrm{ab}$ & $0.907 \mathrm{a}-\mathrm{d}$ & $0.865 \mathrm{a}-\mathrm{e}$ & $0.815 b-e$ & $0.782 \mathrm{c}-\mathrm{e}$ & $0.741 \mathrm{de}$ & $0.853 \mathrm{~B}$ \\
\hline control & $0.970 \mathrm{a}-\mathrm{c}$ & 0.871 a-e & $0.842 \mathrm{a}-\mathrm{e}$ & $0.791 \mathrm{a}-\mathrm{c}$ & $0.700 \mathrm{de}$ & $0.650 \mathrm{e}$ & $0.804 \mathrm{C}$ \\
\hline Mean & $1.003 \mathrm{~A}$ & $0.920 \mathrm{AB}$ & $0.890 \mathrm{~B}$ & 0.843 BC & $0.791 \mathrm{CD}$ & $0.754 \mathrm{D}$ & \\
\hline
\end{tabular}

Values with capital letters in the same column and the same row are not statistically different. Small letters for interaction, according to Duncan 's multiple range test.

$\mathrm{MAP}_{1}=$ modified atmosphere packaging at $7.5 \% \mathrm{O}_{2}+15 \% \mathrm{CO}_{2}$.

$\mathrm{MAP}_{2}=$ modified atmosphere packaging at $10 \% \mathrm{O}_{2}+10 \% \mathrm{CO}_{2} . \quad$ Passive MAP = passive modified atmosphere packaging

The interaction between MAP treatments and storage period were significant in the two seasons. In general, strawberry fruits packed in active MAP resulted in maintaining TA during all storage periods.

\section{Ascorbic acid}

It is clear from Table (6) that ascorbic acid content of strawberry fruits was significantly decreased with the prolongation of storage period in the two seasons. Similar results were obtained by Mohammadi and Hanafi (2014). The decrease in ascorbic acid during storage might be to the higher rate of sugar loss through respiration than water loss through transpiration (Wills et al 1998).

Concerning the effect of MAP treatment, data revealed that active and passive MAP were effective on preventing ascorbic acid degradation during storage and shelf life as compared with untreated 
MAP(control). Moreover, strawberry fruits stored in active $M A P_{1}$ or $M A P_{2}$ were significantly higher in ascorbic acid content during storage period and shelf life with significant differences between them. Passive MAP had slight effect on ascorbic acid preservation. On the other hand, the lowest value of ascorbic acid resulted from untreated MAP (control). Similar results were obtained by Khreba et al (2014) who found that strawberry fruits stored at MAP prevent ascorbic acid degradation during storage. Moreover, high $\mathrm{CO}_{2}$ treatment retarded the change in ascorbic acid content of pepper fruits during storage (Akbudak, 2008). Strawberry fruits packed in MAP reduced respiration rate and vital process, thus reducing the loss of ascorbic acid during storage (Mohammadi and Hanafi, 2014)

As for the interaction between MAP treatments and storage period, data revealed that strawberry fruits stored in active $\mathrm{MAP}_{1}$ was the most effective treatment after 15 days at $0^{\circ} \mathrm{C}+2$ days at $10^{\circ} \mathrm{C}$ in reducing ascorbic acid loss in both seasons.

\section{Anthocyanin}

Anthocyanin content of strawberry fruits was significantly increased during storage period and shelf life (Table 7). These results were in agreement with those obtained by Jouki and Khazaei (2012) and Oliveira et al (2015) who found that fruits became redder and darker along the storage time, due to synthesis of anthocyanin, a pigment contributing to the red color in strawberry.

Concerning the effect of MAP, data recorded that strawberry fruits stored in $\mathrm{MAP}_{1}$ gave the lowest values of anthocyanin content, indicating that decrease in color development and the fruits become less redness. On the contrary, passive MAP and untreated MAP (control).treatment gave the highest values of anthocyanin, which developed more redness. These results were in agreement with Jouki and Khazaei (2012) detected lower anthocyanin concentration in strawberry fruits stored in modified atmosphere. Also Jouki and Khazaei (2012) found that changes in color of

Table 6. Effect of active and passive modified atmosphere packaging on $\mathrm{L}$ ascorbic acid (mg/100g F.W) of strawberry fruits during storage at $0^{\circ} \mathrm{C}$, with an additional 2 days at $10^{\circ} \mathrm{C}$ in $2013-2014$ and $2014-2015$ seasons

\begin{tabular}{|c|c|c|c|c|c|c|c|}
\hline \multirow{3}{*}{ Treatments } & \multicolumn{7}{|c|}{ Storage period (day) } \\
\hline & \multicolumn{6}{|c|}{ 2013-2014 } & \multirow{2}{*}{ Mean } \\
\hline & $0+2$ & $3+2$ & $6+2$ & $9+2$ & $12+2$ & $15+2$ & \\
\hline MAP $_{1}$ & $103.20 \mathrm{a}$ & $102.90 \mathrm{a}$ & $101.90 \mathrm{ab}$ & $97.20 \mathrm{~cd}$ & $95.30 \mathrm{de}$ & $90.80 \mathrm{fg}$ & $98.55 \mathrm{~A}$ \\
\hline $\mathrm{MAP}_{2}$ & $103.00 \mathrm{a}$ & $102.20 \mathrm{ab}$ & $101.40 \mathrm{ab}$ & $95.80 \mathrm{~d}$ & $91.90 \mathrm{f}$ & $86.30 \mathrm{~h}$ & $96.77 \mathrm{~B}$ \\
\hline Passive MAP & $102.30 \mathrm{ab}$ & $101.50 \mathrm{ab}$ & $100.30 \mathrm{ab}$ & 92.70 ef & $88.20 \mathrm{gh}$ & $80.90 i$ & $94.32 \mathrm{C}$ \\
\hline Control & $101.40 \mathrm{ab}$ & $99.40 \mathrm{bc}$ & $96.10 \mathrm{~d}$ & $90.30 \mathrm{fg}$ & $82.70 \mathrm{i}$ & $74.20 \mathrm{j}$ & $90.68 \mathrm{D}$ \\
\hline Mean & $102.48 \mathrm{~A}$ & $101.50 \mathrm{~A}$ & $99.93 \mathrm{~B}$ & $94.00 \mathrm{C}$ & $89.53 \mathrm{D}$ & $83.05 \mathrm{E}$ & \\
\hline \multicolumn{8}{|c|}{ 2014-2015 } \\
\hline MAP $_{1}$ & $101.30 \mathrm{a}$ & $101.00 \mathrm{a}$ & $100.10 \mathrm{a}$ & $96.97 \mathrm{a}-\mathrm{d}$ & $91.47 \mathrm{e}-\mathrm{g}$ & $88.90 \mathrm{gh}$ & $96.62 \mathrm{~A}$ \\
\hline $\mathrm{MAP}_{2}$ & $101.10 \mathrm{a}$ & $100.20 \mathrm{a}$ & $99.30 \mathrm{ab}$ & $95.57 \mathrm{~b}-\mathrm{e}$ & $89.50 \mathrm{~g}$ & $83.57 \mathrm{i}$ & $94.87 \mathrm{~B}$ \\
\hline Passive MAP & $100.40 \mathrm{a}$ & $99.40 a b$ & $98.10 \mathrm{a}-\mathrm{c}$ & $93.23 \mathrm{~d}-\mathrm{g}$ & $84.70 \mathrm{hi}$ & $79.00 \mathrm{j}$ & $92.47 \mathrm{C}$ \\
\hline control & $99.50 \mathrm{ab}$ & $97.50 \mathrm{a}-\mathrm{d}$ & $94.30 \mathrm{c}-\mathrm{f}$ & $90.03 \mathrm{fg}$ & $83.40 \mathrm{ij}$ & $74.20 \mathrm{k}$ & 89.82 D \\
\hline Mean & $100.58 \mathrm{~A}$ & $99.53 \mathrm{AB}$ & $97.95 \mathrm{~B}$ & $93.95 \mathrm{C}$ & $87.27 \mathrm{D}$ & $81.42 \mathrm{E}$ & \\
\hline
\end{tabular}

Values with capital letters in the same column and the same row are not statistically different. Small letters for interaction, according to Duncan 's multiple range test.

$M A P_{1}=$ modified atmosphere packaging at $7.5 \% \mathrm{O}_{2}+15 \% \mathrm{CO}_{2}$.

$\mathrm{MAP}_{2}=$ modified atmosphere packaging at $10 \% \mathrm{O}_{2}+10 \% \mathrm{CO}_{2} . \quad$ Passive MAP = passive modified atmosphere packaging 
Table 7. Effect of active and passive modified atmosphere packaging on anthocyanin content $(\mathrm{mg} / 100 \mathrm{~g}$ F.W.) of strawberry fruits during storage at $0^{\circ} \mathrm{C}$, with an additional 2 days at $10^{\circ} \mathrm{C}$ in $2013-2014$ and $2014-$ 2015 seasons

\begin{tabular}{|c|c|c|c|c|c|c|c|}
\hline \multirow{3}{*}{ Treatments } & \multicolumn{7}{|c|}{ Storage period (day) } \\
\hline & \multicolumn{6}{|c|}{ 2013-2014 } & \multirow{2}{*}{ Mean } \\
\hline & $0+2$ & $3+2$ & $6+2$ & $9+2$ & $12+2$ & $15+2$ & \\
\hline MAP $_{1}$ & $45.00 \mathrm{j}$ & $60.30 \mathrm{~g}-\mathrm{j}$ & $74.00 \mathrm{fg}$ & $78.40 \mathrm{e}-\mathrm{g}$ & $80.00 \mathrm{~d}-\mathrm{f}$ & $82.00 \mathrm{de}$ & 69.95 D \\
\hline $\mathrm{MAP}_{2}$ & $45.30 \mathrm{ij}$ & $63.60 \mathrm{fi}$ & $79.50 \mathrm{~d}-\mathrm{f}$ & 94.10 a-e & 94.10 a-e & 96.20 a-e & $78.80 \mathrm{C}$ \\
\hline Passive MAP & $45.60 \mathrm{ij}$ & $64.20 \mathrm{fh}$ & 81.40 b-e & 97.00 a-d & 104.00 a-e & $108.0 \mathrm{ab}$ & 83.37 B \\
\hline Control & $46.10 \mathrm{~h}-\mathrm{j}$ & $74.00 \mathrm{fg}$ & $97.20 \mathrm{a}-\mathrm{d}$ & $100.00 \mathrm{a}-\mathrm{c}$ & $109.00 \mathrm{ab}$ & $116.00 \mathrm{a}$ & $90.38 \mathrm{~A}$ \\
\hline Mean & $45.50 \mathrm{E}$ & $65.53 \mathrm{D}$ & $83.03 \mathrm{C}$ & $92.38 \mathrm{~B}$ & $96.78 \mathrm{AB}$ & $100.55 \mathrm{~A}$ & \\
\hline \multicolumn{8}{|c|}{ 2014-2015 } \\
\hline MAP $_{1}$ & $39.60 \mathrm{i}$ & $43.00 \mathrm{hi}$ & $50.10 \mathrm{f}-\mathrm{i}$ & $58.30 \mathrm{fg}$ & $75.00 \mathrm{de}$ & $89.00 \mathrm{~b}-\mathrm{d}$ & $59.17 \mathrm{D}$ \\
\hline $\mathrm{MAP}_{2}$ & $40.10 \mathrm{i}$ & $45.00 \mathrm{~g}-\mathrm{i}$ & 62.00 ef & $74.00 \mathrm{de}$ & $80.00 \mathrm{~cd}$ & $91.00 \mathrm{bc}$ & $65.35 \mathrm{C}$ \\
\hline Passive MAP & $40.50 \mathrm{i}$ & $58.00 \mathrm{f}-\mathrm{h}$ & $75.90 \mathrm{de}$ & $92.60 \mathrm{bc}$ & $94.60 \mathrm{~b}$ & $96.80 \mathrm{ab}$ & $76.40 \mathrm{~B}$ \\
\hline control & $39.50 \mathrm{i}$ & $58.33 f g$ & $77.20 \mathrm{de}$ & $96.00 \mathrm{ab}$ & $104.00 \mathrm{ab}$ & $111.20 \mathrm{a}$ & $81.03 \mathrm{~A}$ \\
\hline Mean & $39.93 \mathrm{~F}$ & $51.08 \mathrm{E}$ & 66.30 D & $80.22 \mathrm{C}$ & $88.40 \mathrm{~B}$ & $97.00 \mathrm{~A}$ & \\
\hline
\end{tabular}

Values with capital letters in the same column and the same row are not statistically different. Small letters for interaction, according to Duncan 's multiple range test.

$\mathrm{MAP}_{1}=$ modified atmosphere packaging at $7.5 \% \mathrm{O}_{2}+15 \% \mathrm{CO}_{2}$.

$\mathrm{MAP}_{2}=$ modified atmosphere packaging at $10 \% \mathrm{O}_{2}+10 \% \mathrm{CO}_{2} . \quad$ Passive MAP = passive modified atmosphere packaging

strawberry fruits during storage preceded more slowly in MAP treatment, however, the color of fruits stored at air, changed rapidly. This might be due to that MAP treatment might reduce respiration rate and inhibit certain ripening processes which diminished (lower) the synthesis of anthocyanin (Raid and Jeffrey, 2005).

The favorable effect of MAP treatment in reduction of anthocyanin loss of fruits may be due to that MAP would partially inhibit the increase of polyphenol oxidase, which is associated with the degradation of anthocyanin (Ibrahim et al., 2005).

The interaction between MAP and storage period had a significant effect on fruit anthocyanin's content. In this regard, the lowest value of anthocyanin content was recorded in strawberry fruits stored in $\mathrm{MAP}_{1}$ after 15 days at $0^{\circ} \mathrm{C}+2$ days at $10^{\circ} \mathrm{C}$.

\section{Total sugars}

Results in Table (8) showed that total sugar content of strawberry fruits was decreased with the prolongation of the storage period. These results were in the same line with those obtained by
Khreba et al (2014). This reduction might be due to sugar loss through respiration (Wills et al 1998).

There were significant differences between MAP treatments in total sugars content during storage and shelf life. Moreover, strawberry fruits packed in MAP at the two concentrations resulted in maintain total sugar content. However, active $\mathrm{MAP}_{1}$ was the most effective treatment in reducing total sugars loss. These results were in agreement with those obtained by Ozkaya et al (2009) and Jouki and Khazaei (2012) who found that strawberry fruits stored under MAP increased glucose content as compared with control. The lowest values of total sugar content were recorded with untreated MAP (control). Strawberry fruits stored under MAP might reduce respiration rate, therefore, it can delay the use of total sugars in the enzymatic reactions of respiration (Ozkaya et al 2009).

The interaction between MAP treatment and storage period had significant effect on total sugar content. In this regard, after 15 days of storage at $0^{\circ} \mathrm{C}+2$ days at $10^{\circ} \mathrm{C}$, the highest values of total sugar content was recorded in fruits stored under MAP ${ }_{1}$. 
Table 8. Effect of active and passive modified atmosphere packaging on total sugars (\%) of strawberry fruits during storage at $0^{\circ} \mathrm{C}$, with an additional 2 days at $10^{\circ} \mathrm{C}$ in 2013-2014 and 2014-2015 seasons

\begin{tabular}{|c|c|c|c|c|c|c|c|}
\hline \multirow{3}{*}{ Treatments } & \multicolumn{7}{|c|}{ Storage period (day) } \\
\hline & \multicolumn{6}{|c|}{ 2013-2014 } & \multirow{2}{*}{ Mean } \\
\hline & $0+2$ & $3+2$ & $6+2$ & $9+2$ & $12+2$ & $15+2$ & \\
\hline MAP $_{1}$ & $7.39 \mathrm{a}$ & $7.23 \mathrm{a}-\mathrm{c}$ & $7.11 \mathrm{a}-\mathrm{c}$ & $7.00 \mathrm{a}-\mathrm{d}$ & 6.90 a-e & 6.72 a-e & $7.06 \mathrm{~A}$ \\
\hline $\mathrm{MAP}_{2}$ & $7.28 \mathrm{ab}$ & $7.00 \mathrm{a}-\mathrm{d}$ & 6.64 a-e & $6.28 \mathrm{a}-\mathrm{f}$ & $6.02 \mathrm{a}-\mathrm{f}$ & 5.83 a-f & $6.51 \mathrm{~B}$ \\
\hline Passive MAP & $7.00 \mathrm{a}-\mathrm{d}$ & 6.50 a-f & $6.00 \mathrm{a}-\mathrm{f}$ & $5.72 c-g$ & $5.51 \mathrm{~d}-\mathrm{g}$ & $5.00 \mathrm{fg}$ & $5.96 \mathrm{C}$ \\
\hline control & $6.92 \mathrm{a}-\mathrm{e}$ & $6.33 \mathrm{a}-\mathrm{f}$ & $5.82 \mathrm{~b}-\mathrm{f}$ & $5.41 \mathrm{e}-\mathrm{g}$ & $5.00 \mathrm{fg}$ & $4.20 \mathrm{~g}$ & $5.61 \mathrm{D}$ \\
\hline Mean & $7.15 \mathrm{~A}$ & $6.77 \mathrm{AB}$ & $6.39 \mathrm{BC}$ & $6.10 \mathrm{C}$ & $5.86 \mathrm{CD}$ & $5.44 \mathrm{D}$ & \\
\hline \multicolumn{8}{|c|}{ 2014-2015 } \\
\hline MAP $_{1}$ & $6.90 \mathrm{a}$ & $6.74 \mathrm{a}$ & $6.51 \mathrm{ab}$ & $6.30 \mathrm{a}-\mathrm{c}$ & $6.10 \mathrm{a}-\mathrm{d}$ & $5.94 a-d$ & $6.42 \mathrm{~A}$ \\
\hline $\mathrm{MAP}_{2}$ & $6.70 \mathrm{a}$ & $6.34 \mathrm{a}-\mathrm{c}$ & $6.02 \mathrm{a}-\mathrm{d}$ & 5.71 a-e & $5.42 \mathrm{a}-\mathrm{f}$ & $5.10 \mathrm{~b}-f$ & $5.88 \mathrm{~B}$ \\
\hline Passive MAP & $6.52 \mathrm{ab}$ & $6.00 \mathrm{a}-\mathrm{d}$ & $5.41 \mathrm{a}-\mathrm{f}$ & $5.33 \mathrm{a}-\mathrm{d}$ & $4.84 \mathrm{c}-\mathrm{f}$ & 4.32 ef & $5.40 \mathrm{C}$ \\
\hline control & $6.33 \mathrm{a}-\mathrm{c}$ & 5.84 a-e & $5.31 \mathrm{a}-\mathrm{f}$ & $5.00 \mathrm{~b}-\mathrm{f}$ & $4.51 \mathrm{~d}-\mathrm{f}$ & $4.00 \mathrm{f}$ & 5.17 D \\
\hline Mean & $6.61 \mathrm{~A}$ & $6.23 \mathrm{AB}$ & $5.81 \mathrm{BC}$ & $5.59 \mathrm{C}$ & 5.22 CD & $4.84 \mathrm{D}$ & \\
\hline
\end{tabular}

Values with capital letters in the same column and the same row are not statistically different. Small letters for interaction, according to Duncan 's multiple range test.

$\mathrm{MAP}_{1}=$ modified atmosphere packaging at $7.5 \% \mathrm{O}_{2}+15 \% \mathrm{CO}_{2}$.

$\mathrm{MAP}_{2}=$ modified atmosphere packaging at $10 \% \mathrm{O}_{2}+10 \% \mathrm{CO}_{2} . \quad$ Passive MAP = passive modified atmosphere packaging

\section{CONCLUSION}

From the previous results, it could be concluded that storage of strawberry fruits at active MAP of $7.5 \% \mathrm{O}_{2}+15 \% \mathrm{CO}_{2}$ improved storability of fruits, maintaining fruit quality and gave fruits with agood appearance till 15 days at $0^{\circ} \mathrm{C}+2$ days at $10^{\circ} \mathrm{C}$ without decay.

\section{REFERANCES}

A.O.A.C. 2000. Association of Official Analytical Chemists. Washington DC. International $17^{\text {th }}$ Edition, Revision I.

Akbudak, B. 2008. Effect of polypropylene and polyvinyl chloride plastic film packaging materials on the quality of yalovacharleston pepper (Capsicum annuum L.) during storage. Food Sci. Technol. Res., 14(1), 5-11.

Allende, A., Marin A., Buendia B. and Tomas F. 2007. Impact of combined postharvest treatments (UV-C light, gaseous $\mathrm{O}_{3}$, super atmospheric $\mathrm{O}_{2}$ and high $\mathrm{Co}_{2}$ ) on health promoting compounds and shelf-life of strawberries. Postharvest Biology and Technology, 46, 201-211.

Attia, A.A. 2005. Effect of modified atmosphere storage on keeping quality of strawberry fruits and transplants. Thesis ph. D., faculty of Ain Shams University. Egypt. 86 p.
Barrios, S., Lema P. and Marra F. 2014. Modelling passive modified atmosphere packaging of strawberries: Numerical analysis and model validation. International Food Research Journal 21(2), 507-515.

Cheour, F.J., Willemot J., Arul J., Desjardins J., Mathlouf P.M., Charest F.M. and Gosselin A. 1990. Foliar application of calcium chloride delays postharvest ripening of strawberry. J. Amer. Soc. Hort. Sci., 115(5), 785-792.

Day, B.P. 1990a. Modified atmosphere packaging of selected prepared fruit and vegetables. In: Processing and Quality of Foods (ed. P. Zeuthen), Elsevier Science publishers, Barking, Essex, pp. 230-233.

El-Kazzaz, M.K., Sommer and Fortlage R.J. 1983. Effect of different atmospheres on postharvest decay and quality of fresh strawberries. Phytopathology 73, 282-285.

Farber, J.M. 1991. Microbiological aspects of modified atmosphere packaging technology. A Review J. Food Prot. 54, 58-70.

Harker, F.R., Elgar H.J., Watkins C.B., Jackson P.J. and Hallett I.C. 2000. Physical and mechanical changes in strawberry fruit after high carbon dioxide treatments. Postharvest Biol. Technol., 19(2),139-146.

Holcroft, D.M. and Kader, A.A. 1999. Controlledatmosphere-induced changes in $\mathrm{pH}$ and organic acid metabolism may affect color of stored 
strawberry fruit. Postharvest Biol. Technol. 17, 19-32.

Ibrahim, R., Osman, A., Saari, N. and Abdul Rahman, R. 2005. Effect of several packaging film on biochemical characteristics and microbiological counts of shredded cabbage at different storage condition. Journal of Food Agriculture and Environment. 3(2), 20-27.

Jouki, M. and Khazaei, N. 2012. The effect of modified atmosphere packaging and calcium chloride dripping on the quality and shelf life of Kurdistan strawberries. J. Food Process Technol, 3, 2-7.

Khreba, A.H., Hassan, A.H., Emam, M.S. and Atala, S.A. 2014. Effect of some pre and postharvest treatments on quality and storability of strawberry fruits. Journal of American Science. 10(11), 239-248.

Mohammadi, H. and Hanafi, Q. 2014. Effect of different atmospheres on quality changes of Kurdistan strawberry. J. Food Chem. Nutr. 2 (2), 61-69.

Nielsen, T. and Leufven, A. 2008. The effect of modified atmosphere packaging on the quality of Honeoye and Korona strawberries. Food Chemistry, 107, 103-1063.

Oliveira, A., Alexandre, E.M., Coelho, M., Gomes, M.H., Almeida, D.P. and Pintado, M. 2015. Effect of modified atmosphere on polyphenols during storage of pasteurised strawberry purees. Food science and Technology 60, 377-384.

Ozkaya, O., Dündar, O., Scovazzo, G.C. and Volpe, G. 2009. Evaluation of quality parameters of strawberry fruits in modified atmosphere packaging during storage. African J. of Biotechnology. 85, 789-793.

Raid, G.S. and Jeffrey, K.B. 2005. Simulated long distance transport of strawberry in a passive modified atmosphere marine container. Proc. Fla. State Hort. Soc. 111, 396-399.

Shehata, S.A., Emam, M.S. and Abou EL-Wafa S.M. 2009. Effect of active and passive modified atmosphere packaging on the quality attributes of Strawberries. Annals of Agric. Sci., Moshtohor, 48(2), 119-130.

Snedecor, G.W. and Cochran, W.G. 1991. Statistical Methods. $8^{\text {th }}$ Ed., lowa State Univ. Press, lowa, USA.

Thompson, A.K. 1996. Post-harvest Technology of Fruits and Vegetables, Blackwell, Oxford.

Vermeiren, L., Devliegere, F. and Kruijf, B.M. 1999. Developments in the active packaging of foods. Trends Food Sci. Tech. 10, 77-86.
Wills, R.B.H. and Kim, G.H. 1995. Effect of ethylene on postharvest life of strawberries. Postharvest Biol. Technol., 6(3), 249-255.

Wills, R., Mcglasson, B., Graham, D. and Joyce, D. 1998. Postharvest: An Introduction to the Physiology and Handling of fruit, Vegetables and Ornamentals. Ed.: CAB International, Wallingford, UK. Zagazig Jour. Agric. Res. 17, 877-882.

Zhang, H., Wang, L., Dong, Y., Jiang, S., Cao, J. and Meng, R. 2007. Postharvest biological control of gray mold decay of strawberry with Rhodotorulaglutinis Biol. Contr. 40, 287-292. Merghaney, M.M. 1997. Effect of irrigation system and nitrogen level on vegetative growth, yield components and some chemical composition of tomato plants grown in newly reclaimed sandy soils. Ann. Agric. Sci. Moshtohor. 35(2), 965- 981.

Navarrete, M. and Jeannequin, B. 2000. Effect of frequency of axillary bud pruning on vegetative growth and fruit yield in greenhouse tomato crops. Scienta- Horti. 86(3), 197-210.

Olanike, A. and Madramootoo, C. 2014. Response of greenhouse- grown bell pepper (Capsicum annuum L.) to variable irrigation. Canadian Journal of Plant Science, 94(2), 303- 310.

Pane, C., Celano, G., Piccolo, A., Villecco, D., Spaccini, R., Palese, A.M. and Zaccardelli, M. 2015. Effects of on-farm composted tomato residues on soil biological activity and yields in a tomato cropping system. Chemical and Biological Technologies in Agriculture (2), 2-13.

Panigrahi, B., Roy, D.P. and Panda, S.N. 2010. Water use and yield response of tomato as influenced by drip and furrow irrigation. International Agricultural Engineering Journal 19(1), 19-30.

Saleh, M.I., Ozawa, K. and Khondaker, N.A. 2007. Effect of irrigation frequency and timing on tomato yield. soil water dynamics and water use efficiency under drip irrigation. Eleventh International Water Technology Conference IWTC11 Sharm El-Sheikh, Egypt.

Snedecor, G.M. and Cochran, W.G. 1980. Statistical methods, Sixth Edition, Lowa State Univ. Press, Amer. Lowa, USA.

Srinivas, K., Hegde, D.M. and Havanagi, G.V. 1989. Plant water relations, canopy temperature, yield and water use efficiency of watermelon (Citrullus lanatus Thunb.) Matsum et Nakai under drip and furrow irrigation. J. Hort. Sci., 64(1), 115-124. 